\title{
Pengaruh Trait Conscientiousness, Leader-Member Exchange dan Masa Kerja terhadap Perilaku Berbagi Pengetahuan Guru SMA
}

\section{The Effect of Trait Conscientiousness, Leader-Member Exchange and Tenure on Senior High School Teacher's Knowledge Sharing Behavior}

\author{
Farhanah Murniasih $^{*}$ \& Ali Nina Liche Seniati* ${ }^{* *}$ \\ Fakultas Psikologi, Universitas Indonesia, Indonesia \\ Diterima; 22-04-2019; Disetujui: 21-06-2019; Dipublish: 30-06- 2019 \\ ${ }^{*}$ Corresponding author: E-mail: farhanah.murniasih@ui.ac.id
}

\begin{abstract}
Abstrak
Penelitian ini bertujuan untuk mengetahui pengaruh trait conscientiousness guru, leader-member exchange, dan masa kerja guru terhadap perilaku berbagi pengetahuan guru Sekolah Menengah Atas. Penelitian dilakukan pada 228 guru Sekolah Menengah Atas yang mengajar di wilayah JABODETABEK (Jakarta, Bogor, Depok, Tangerang, Bekasi) dan memiliki pengalaman kerja minimal 1 tahun. Teknik analisis dalam penelitian ini menggunakan analisis multiple regression. Desain penelitian ini adalah non-eksperimental dengan pendekatan kuantitatif. Teknik pengambilan sampel dalam penelitian ini menggunakan snowball sampling. Perilaku berbagi pengetahuan diukur dengan menggunakan Skala Perilaku Berbagi Pengetahuan, trait conscientiousness diukur dengan menggunakan skala NEO-4, serta persepsi kualitas hubungan atasan dan bawahan diukur dengan menggunakan skala LeaderMember Exchange Multi-Dimensional (LMX-MDM). Hasil penelitian menunjukkan bahwa trait conscientiousness guru dan leader-member exchange guru berpengaruh secara signifikan terhadap perilaku berbagi pengetahuan pada guru SMA, namun lama kerja ditemukan tidak berpengaruh secara signifikan terhadap perilaku berbagi pengetahuan guru. Trait conscientiousness guru memiliki sumbangan paling besar terhadap perilaku berbagi pengetahuan guru.
\end{abstract}

Kata Kunci: Conscientiousness, Guru, Leader-Member Exchange, Masa Kerja, Perilaku Berbagi Pengetahuan

\begin{abstract}
This study aims to determine the effect of teacher's conscientiousness trait, leader-member exchange, and tenure on teacher's knowledge sharing behavior. The study was conducted on 228 high school teachers who taught in the JABODETABEK (Jakarta, Bogor, Depok, Tangerang, Bekasi) area and had a minimum of 1 year work experience. The analysis technique uses multiple regression analysis. The design of this study is non-experimental with a quantitative approach. The sampling technique in this study used snowball sampling. Teacher's knowledge sharing behavior is measured using the Knowledge Sharing Behavior Scale, trait conscientiousness is measured using NEO-4 scale, and perceptions of the quality of supervisor and subordinate relationships is measured using a scale of Multi-Dimensional Exchange Leaders (LMX-MDM). Result from this study showed that teacher's trait conscientiousness and leadermember exchange had a significant effect on senior high school teacher's knowledge sharing behavior, but tenure did not have significant effect on teacher's knowledge sharing behavior. Teacher's conscientiousness trait has the greatest contribution to teacher's knowledge sharing behavior.
\end{abstract}

Keywords: Conscientiousness, Teacher, Leader-Member Exchange, Tenure, Knowledge Sharing Behavior

How to Cite: Murniasih, F. \& Seniati, A.N.L. (2019). Pengaruh Trait Conscientiousness, Leader-Member Exchange dan Masa Kerja terhadap Perilaku Berbagi Pengetahuan pada Guru SMA, Jurnal Diversita, 5 (1): 9-18. 


\section{PENDAHULUAN}

Guru merupakan tokoh kunci dalam kualitas pendidikan di sekolah. Pengembangan profesional guru saat ini dilihat sebagai kunci dalam upaya meningkatkan pendidikan (Chen, 2011), dan salah satu caranya adalah dengan berbagi pengetahuan. Berbagi pengetahuan merupakan kegiatan belajar dimana guru tidak hanya meningkatkan profesionalitas diri mereka sendiri, tetapi juga berkontribusi pada pengembangan profesional rekan-rekan mereka (Runhaar \& Sanders, 2015). Peluang untuk berbagi pengetahuan dan kolaborasi di antara para guru semakin diakui sebagai komponen penting dari pengembangan profesional guru yang berkelanjutan.

Berbagi pengetahuan adalah proses dimana individu saling bertukar (memberikan dan memperoleh) pengetahuan (baik pengetahuan tacit maupun eksplisit) dan bersama-sama menciptakan pengetahuan yang baru (van den Hooff \& de Ridder, 2004). Berbagi pengetahuan dapat dilakukan dalam setting formal seperti workshop, seminar, mentoring ataupun informal seperti diskusi santai selama istirahat dan pertemuan informal (Matić, Cabrilo, Grubić-Nešić, \& Milić, 2017).

Berbagi pengetahuan merupakan hal penting dalam meningkatkan keunggulan kompetitif di dalam organisasi, tidak terkecuali di sekolah. Penelitian perilaku berbagi pengetahuan sudah banyak dilakukan di bidang bisnis namun masih jarang dilakukan di institusi pendidikan, terutama pada guru (Badar \& Seniati, 2017; Rismark \& Sølvberg, 2011). Berbagi pengetahuan penting dalam organisasi non-profit (Mallasi \& Ainin, 2015) seperti sekolah, karena sekolah berperan dalam menciptakan ilmu pengetahuan. Banyak faktor yang mempengaruhi kecenderungan individu untuk berbagi pengetahuan dengan orang lain di lingkungan kerja. Faktor internal (individu) antara lain big five personality trait (Agyemang, Dzandu, Boateng, 2016; Gupta, 2008), efikasi diri (Runhaar \& Sanders, 2015), dan trust (Badar \& Seniati, 2017). Faktor eksternal (organisasi) yang mempengaruhi berbagi pengetahuan antara lain budaya organisasi (Borges, 2013), iklim organisasi (Kishore, Shandu \& Goh, 2015), dan kepemimpinan (Carmeli, Atwater, \& Levi, 2011; Sharifkhani, Pool, \& Asian, 2016; Kim, Han, Son, Yun, 2017).

Beberapa peneliti meyakini bahwa trait kepribadian merupakan kunci antesenden perilaku manusia dan oleh karena itu memiliki potensi dalam mempengaruhi perilaku berbagi pengetahuan individu (Agyemang, Dzandu, \& Boateng, 2016). Big five personality (McCrae \& Costa, 2003) merupakan teori kepribadian yang paling dapat memberikan gambaran sifat kepribadian individu secara umum. Dalam penelitian ini, peneliti hanya meneliti trait conscientiousness.

Conscientiousness merupakan kecenderungan untuk bertanggung jawab, dapat diandalkan, gigih, tepat waktu, pekerja keras, dan berorientasi pada pekerjaan (Latham \& Pinder, 2005). Di antara kelima trait big five personality, conscientiousness menunjukkan hubungan paling konsisten dengan kinerja di berbagai pengaturan tugas. Individu dengan trait conscientiousness tinggi berorientasi pada pencapaian, motivasi diri, dan tugas (Gupta, 2008). Oleh sebab 
itu, mereka seharusnya memiliki kinerja yang lebih baik di tempat kerja, fokus pada tugas-tugas kerja dan memiliki inisiatif dalam memecahkan masalah. Dengan demikian, trait conscientiousness dianggap sebagai karakteristik yang diinginkan dari karyawan secara umum (Judge, Rodell, Klinger, Simon, \& Crawford, 2013).

Pada beberapa penelitian yang telah menguji hubungan kepribadian dan berbagi pengetahuan menunjukkan bahwa trait conscientiousness memiliki hubungan positif dengan berbagi pengetahuan (Gupta, 2008; Matzler, Renzl, Mueller, Mooradian, \& Krogh, 2011). Individu dengan trait conscientiousness tinggi cenderung terlibat dalam kegiatan yang berada di luar peran dan tanggung jawab mereka, sehingga mereka diharapkan lebih bersedia untuk berbagi pengetahuan (Matzler et al., 2011; Raducanu, 2012). Penelitian Agyemang, Boateng, dan Dzandu (2016) menunjukkan hasil berlawanan, trait conscientiousness tidak memiliki pengaruh signifikan terhadap perilaku berbagi pengetahuan. Munculnya perbedaan pada hasil penelitian sebelumnya membuat peneliti tertarik untuk memperjelas dampak dari trait conscientiousness terhadap perilaku berbagi pengetahuan.

Faktor lain yang mempengaruhi perilaku berbagi pengetahuan adalah kepemimpinan. Beberapa individu tidak selalu berbagi pengetahuan mereka dan mungkin tidak mau berbagi sebanyak yang diinginkan organisasi (Jolaee, Md Nor, Khani, \& Md Yusoff, 2014). Pemimpin, sebagai agen organisasi, memiliki kemampuan serta potensi mendorong karyawan mengatasi konflik atau kekhawatiran berbagi pengetahuan.
Pemimpin berperan penting dalam membimbing arahan, memberikan tugas, serta memotivasi bawahan (Seba, Rowley, \& Lambert, 2012). Mempertimbangkan posisi pemimpin yang kuat, leadermember exchange (LMX) bisa menjadi faktor kuat dalam mempromosikan berbagi pengetahuan. Kurangnya dukungan dari manajemen dan kepemimpinan yang tidak baik bisa menghambat keberhasilan individu dalam berbagi pengetahuan di dalam organisasi (Asrar-ul-Haq \& Anwar, 2016).

LMX adalah hubungan pertukaran diadik antara pemimpin dan bawahan (Kim, Han, Son, \& Yun, 2017). Di lingkungan kerja, karyawan mengembangkan berbagai hubungan pertukaran sosial, termasuk hubungan LMX. Berdasarkan teori social exchange dalam memahami berbagi pengetahuan, pemimpin dan karakteristik organisasi adalah prediktor berbagi pengetahuan (Wang \& Noe, 2010). Berbagi pengetahuan melibatkan upaya dan biaya sehingga individu akan berbagi pengetahuan mereka ketika menerima perlakuan positif atau sumber daya dari pemimpin dalam organisasi (Kim, \& Yun, 2015). Dalam hubungan LMX berkualitas tinggi, para pemimpin memberi karyawan tingkat kepercayaan, dukungan, dan interaksi yang tinggi (Sharifkhani, Pool, \& Asian, 2016). Akibatnya, guru akan merasakan kewajiban yang kuat untuk bekerja di luar peran mereka dan dengan demikian dapat memilih untuk meningkatkan tingkat berbagi pengetahuan sebagai cara positif memenuhi kewajiban timbal balik pada Kepala Sekolah.

Selain kedua faktor di atas, masa kerja juga memiliki hubungan dengan 
berbagi pengetahuan. Masa kerja berkaitan dengan jumlah tahun atau pengalaman kerja seorang karyawan dalam organisasi yang mungkin menjadi faktor penting yang dapat memengaruhi keterlibatan karyawan dalam perilaku berbagi pengetahuan (Olowodunoye, 2015). Seiring berjalannya waktu selama bertahun-tahun, tingkat kepercayaan dan juga keterlibatan mereka dalam berbagi pengetahuan meningkat. Penelitian Ng dan Feldman (2010) menunjukkan bahwa masa kerja berhubungan positif dengan kinerja. Semakin lama masa kerja, semakin banyak pengalaman yang didapat dan memiliki tingkat kinerja yang lebih baik.

Sejalan dengan hal tersebut, hasil penelitian Waston \& Hewett (2006) menunjukkan bahwa masa kerja memiliki hubungan positif dan signifikan dengan berbagi pengetahuan. Semakin lama karyawan bekerja pada perusahaan tertentu, semakin banyak pengetahuan yang mereka miliki, sehingga mendorong karyawan menjadi lebih merasa bertanggung jawab untuk memastikan perusahaan mendapatkan keuntungan dari pengetahuannya tersebut, dan salah satu cara yang bisa dilakukan adalah dengan berbagi pengetahuan. Namun, Sarti (2018) dalam penelitiannya menemukan hasil yang berbeda, bahwa masa kerja berhubungan secara negatif dengan perilaku berbagi pengetahuan. Menurutnya, karyawan yang sudah lebih lama bekerja akan mempertimbangkan mengenai kompetisi dengan karyawan yang baru masuk kerja.

Berdasarkan uraian di atas dan mempertimbangkan pentingnya faktor individu serta organisasi sebagai penyebab perilaku berbagi pengetahuan, maka tujuan penelitian adalah melihat pengaruh trait conscientiousness, leadermember exchange, dan masa kerja terhadap perilaku berbagi pengetahuan pada Guru SMA.

\section{METODE PENELITIAN}

Penelitian ini adalah penelitian kuantitatif dengan metode survei. Partisipan berjumlah 228 guru SMA di wilayah JABODETABEK dan memiliki pengalaman mengajar minimal 1 tahun. Karakteristik sampel tersebut dipilih atas pertimbangan guru yang menjadi partisipan sudah memiliki pengalaman terhadap pekerjaannya dan interaksi dengan kepala sekolah sebagai pemimpin di tempat kerjanya. Teknik pengambilan sampel menggunakan non-probability sampling. Partisipan masing-masing dibagikan kuisioner yang berisi skala perilaku berbagi pengetahuan, conscientiousness dan leader-member exchange dan disebarkan menggunakan google form melalui whatsapp.

Pengukuran perilaku berbagi pengetahuan menggunakan skala Perilaku Berbagi Pengetahuan yang dikembangkan dari konsep teori Hooff dan Ridder (2004) dan sudah diujicobakan oleh peneliti pada sampel guru SMA dengan nilai reliabilitas sebesar 0,85. Pengukuran kepribadian menggunakan versi pendek NEO-4 (Costa \& McCrae, 1992) yang telah diadaptasi ke dalam Bahasa Indonesia oleh Seniati (2002). Penelitian ini hanya menggunakan 18 item yang mengukur conscientiousness dengan reliabilitas 0,88. Pengukuran leader-member exchange menggunakan skala LMX-MDM (Linden \& Maslyn, 1998) yang telah diadaptasioleh Istono (2018) ke dalam Bahasa Indonesia dan sudah 
diujicobakan pada pekerja Indonesia dengan reliabilitas 0,88 . Ketiga skala menggunakan skala Likert dari rentang 1 (sangat tidak setuju) sampai 6 (sangat setuju). Peneliti menguji hipotesis dengan teknik analisis regresi berganda dengan menggunakan software SPSS 23.0.

\section{HASIL DAN PEMBAHASAN}

Penelitian ini berjumlah 228 partisipan setelah tidak mengikutsertakan sejumlah partisipan yang tidak sesuai dengan karakteristik partisipan yang dibutuhkan maupun melakukan kesalahan dalam menjawab pertanyaan kontrol. Secara keseluruhan, partisipan terdiri dari 160 perempuan dan 68 laki-laki. Pengelompokkan usia partisipan dalam penelitian ini didasarkan pada perkembangan karir Donald (2012), 12,7 $\%$ berada pada tahap exploration (usia 1524 tahun), 67,5\% partisipan berada pada tahap establishment (usia 25-44 tahun), dan 19,7\% partisipan berada pada tahap maintenance.

Tabel 1 Deskripsi Karakterisik Partisipan

\begin{tabular}{cccc}
\hline \multicolumn{2}{c}{ Karakteristik Partisipan } & $\mathrm{N}$ & $\%$ \\
\hline Jenis & Perempuan & 160 & $70,2 \%$ \\
Kelamin & Laki-laki & 68 & $29,8 \%$ \\
& & & \\
Usia & 15-24 Tahun & 29 & $12,7 \%$ \\
& 25-44 Tahun & 154 & $67,5 \%$ \\
& 44-64 Tahun & 45 & $19,7 \%$ \\
Masa & < 2 Tahun & 27 & $11,8 \%$ \\
Kerja & 2- 10 Tahun & 126 & $55,3 \%$ \\
& $>$ 10 Tahun & 75 & $32,9 \%$ \\
Jenis & Negeri & 85 & $37,3 \%$ \\
Sekolah & Swasta & 143 & $62,7 \%$ \\
Wilayah & Jakarta & 81 & $35,5 \%$ \\
Sekolah & Bogor & 34 & $14,9 \%$ \\
& Depok & 34 & $14,9 \%$ \\
& Tangerang & 48 & $21,1 \%$ \\
& Bekasi & 31 & $13,6 \%$ \\
\hline
\end{tabular}

Berdasarkan tahapan masa kerja Morrow dan Elroy (1987), 11,8\% partisipan memiliki masa kerja kurang dari sama dengan 2 tahun (tahap perkembangan), $\quad 55,3 \%$ responden memiliki masa kerja 2-10 tahun (tahap lanjutan), dan $32,9 \%$ responden memiliki masa kerja di atas 10 tahun (tahap pemeliharaan). Sebanyak 85 guru $(37,3 \%)$ berasal dari sekolah negeri dan 143 guru $(62,7 \%)$ dari sekolah swasta. Sedangkan dari data wilayah mengajar, lebih banyak partisipan merupakan guru SMA di wilayah Jakarta yaitu sejumlah 81 guru $(35,5 \%)$, diikuti di Tangerang sebanyak 48 guru (21,1\%), kemudian Bogor dan Depok masing-masing sebanyak 34 guru $(14,9 \%)$ dan Bekasi sebanyak 31 guru (13,6\%).

Kemudian peneliti membuat kategorisasi menjadi dua kategori yaitu rendah dan tinggi berdasarkan nilai skor total. Hasil kategorisasi masing-masing variabel dapat dilihat pada tabel di bawah ini.

Tabel 2 Gambaran Partisipan Berdasarkan Variabel

\begin{tabular}{ccc}
\hline Variabel & M & Kategori \\
\hline Perilaku Berbagi & 117,16 & Tinggi \\
Pengetahuan & & \\
Conscientiousness & 83,83 & Tinggi \\
Leader-Member Exchange & 46,61 & Tinggi \\
\hline
\end{tabular}

Hasil gambaran skor yang diperoleh dari masing-masing variabel pada tabel 2 menunjukkan: Pertama, dalam variabel perilaku berbagi pengetahuan, skor partisipan pada perilaku berbagi pengetahuan berada pada taraf tinggi. Hal ini menunjukkan bahwa guru-guru dalam penelitian ini sudah menerapkan perilaku berbagi pengetahuan di lingkungan sekolah, serta aktif dalam menerima dan juga memberikan pengetahuan kepada 
sesama rekan guru. Kedua, skor partisipan conscientiousness berada pada taraf tinggi. Hal ini menunjukkan bahwa guru - guru dalam penelitian ini memiliki karakteristik dapat diandalkan, patuh, bertanggung jawab, rajin, pekerja keras, terorganisir, dan berorientasi pada tujuan.

Ketiga, persepsi partisipan terhadap kualitas hubungan atasan-bawahan (leader-member exchange) berada pada taraf tinggi. Hal ini menunjukkan bahwa guru mempersepsikan kualitas hubungan pertukaran dengan kepala sekolah berkualitas tinggi, dimana kepala sekolah memiliki interaksi dan memberikan tingkat kepercayaaan serta dukungan yang tinggi kepada guru.

\section{Hasil Analisa Statistik}

Berdasarkan hasil analisis regresi berganda, diperoleh nilai F sebesar 39.697 dan sig $(p)=0,000$ dengan hasil $\mathrm{R}^{2}$ sebesar 0,347 , artinya proporsi varians dari perilaku berbagi pengetahuan yang dijelaskan oleh trait conscientiousness, leader-member exchange, masa kerja guru adalah sebesar $34,7 \%$, sedangkan sisanya dipengaruhi oleh variabel lain di luar penelitian ini. Artinya terdapat pengaruh yang signifikan dari trait conscientiousness, leader-member exchange, dan masa kerja terhadap perilaku berbagi pengetahuan guru.
Tabel 3 Hasil Uji Regresi Parsial

\begin{tabular}{cccc}
\hline Variabel & $\beta$ & $\begin{array}{c}\text { Sig. } \\
(\rho)\end{array}$ & Ket. \\
\hline $\begin{array}{c}\text { Conscientiousness } \\
\text { terhadap perilaku }\end{array}$ & & & \\
$\begin{array}{c}\text { berbagi pengetahuan } \\
\text { Leader-member }\end{array}$ & 0,51 & 0,00 & Diterima \\
$\begin{array}{c}\text { exchange terhadap } \\
\text { perilaku berbagi } \\
\text { pengetahuan }\end{array}$ & 0,15 & 0,01 & Diterima \\
$\begin{array}{c}\text { Masa kerja terhadap } \\
\text { perilaku berbagi } \\
\text { pengetahuan }\end{array}$ & 0,01 & 0,79 & Ditolak \\
\hline
\end{tabular}

Tabel 3 menunjukkan bahwa dari ketiga variabel independen yang diuji, terdapat dua variabel yang memiliki pengaruh signifikan terhadap perilaku berbagi pengetahuan guru, yaitu trait conscientiousness dan leader member exchange. Hasil koefisien regresi trait conscientiousness dan perilaku berbagi pengetahuan sebesar 0,507 dengan sig. = $0,000(p<0,05)$ yang berarti ada pengaruh secara positif dan signifikan trait conscientiousness terhadap perilaku berbagi pengetahuan. Hasil positif dan signifikan tersebut menunjukkan bahwa semakin tinggi conscientiousness guru maka semakin tinggi perilaku berbagi pengetahuannya.

Koefisien regresi leader-member exchange dan perilaku berbagi pengetahuan adalah sebesar 0,152 dengan signifikansi $0,014 \quad(p<0,05)$ yang berarti ada pengaruh secara postif dan signifikan leader-member exchange terhadap perilaku berbagi pengetahuan. Dengan demikian, semakin tinggi leader-member exchange maka semakin tinggi perilaku berbagi pengetahuan guru. Namun, masa kerja guru ditemukan tidak mempengaruhi secara signifikan perilaku berbagi pengetahuan guru. Hasil koefisien 
regresi adalah sebesar 0,015 dengan nilai signifikansi $0,788 \quad(p>0,05)$. Dari ketiga variabel prediktor tersebut, conscientiousness yang memberikan sumbangan paling besar, yaitu 32,7\% dalam varians perilaku berbagi pengetahuan.

Hasil analisis regresi berganda menunjukkan bahwa secara keseluruhan, trait conscientiousness guru dan leadermember exchange memiliki pengaruh signifikan terhadap perilaku berbagi pengetahuan guru. Hal ini berarti bahwa guru yang memiliki trait conscientiousness yang tinggi dan mempersepsikan kualitas hubungan dengan atasannya kuat akan lebih mau berbagi pengetahuan dengan sesama rekan guru. Konsisten dengan hasil penelitian sebelumnya yang menunjukkan bahwa trait conscientiousness memengaruhi perilaku berbagi pengetahuan.

Berdasarkan pendapat Matzler et al. (2011), individu dengan trait conscientiousness tinggi cenderung terlibat dalam kegiatan yang berada di luar peran serta tanggung jawab mereka, sehingga mereka lebih bersedia untuk berbagi pengetahuan. Sejalan dengan hal tersebut, Cabrera et al. (2006) menyatakan bahwa ketika individu yang bertanggung jawab, gigih, dan pekerja keras menganggap bahwa memberikan pengetahuan adalah bagian dari tugas mereka, mereka cenderung untuk melakukan apa yang diharapkan dari mereka. Selain itu, pekerjaan akademik membuat guru memiliki karakteristik yang membuat mereka patuh, bertanggung jawab, rajin, terorganisir, pekerja keras dan berorientasi pada prestasi sehingga hal ini dapat menjadi alasan guru berpartisipasi dalam kegiatan berbagi pengetahuan (Lotfi, Muktar, Ologblo, \& Chiemek, 2016).

Perilaku berbagi pengetahuan lebih mudah muncul bila ada kedekatan antara pemimpin dan karyawan yang dipimpin. Teori leader member exchange membahas mengenai pengaruh kedekatan antara pemimpin dan anggota yang dipimpin dalam pengambilan keputusan. Hubungan pertukaran (exchange relationship) antara pemimpin dan bawahan membuat karyawan merasa nyaman berada bersama pemimpinnya (Robbins \& Judge, 2015). Dalam pertukaran pemimpinbawahan yang berkualitas tinggi, para pemimpin memberi karyawan tingkat kepercayaan, dukungan, dan interaksi yang tinggi. Pemimpin memberikan manfaat terkait pekerjaan yang diinginkan oleh bawahan, seperti tugas yang menarik, memberikan tanggung jawab tambahan, dan imbalan yang lebih besar, kemudian bawahan, sebagai imbalan atas hasil yang diinginkan ini, menjadi termotivasi untuk berkomitmen pada pekerjaan dan setia kepada pemimpin (Sharifkhani, Pool, \& Asian, 2016).

Berdasarkan norma timbal balik, pertukaran sosial menjelaskan bahwa menerima sumber daya dan dukungan dari pemimpin akan menciptakan rasa kewajiban untuk membalas kembali individu (Blau, 1964). Perasaan kewajiban untuk membalas dapat berupa peningkatan loyalitas, upaya, atau tindakan positif lainnya, seperti berbagi pengetahuan antara sesama rekan guru. Pemimpin sebagai agen penting di tempat kerja memainkan peran penting dalam mempengaruhi persepsi perilaku bawahan. Ketika guru mendapatkan kepercayaan dan dukungan dari kepala 
sekolah, guru akan cenderung untuk berbagi pengetahuan sebagai bentuk timbal balik. Dengan kata lain, kualitas tinggi hubungan pertukaran antara kepala sekolah dan guru menghasilkan manfaat atau sumber daya yang tinggi, akibatnya guru cenderung melakukan upaya lebih dengan berbagi pengetahuan.

Berlawanan dengan hasil penelitianpenelitian sebelumnya (Waston \& Hewett, 2006; Ng \& Feldman, 2010; Sarti, 2018) yang menyatakan bahwa masa kerja mempengaruhi perilaku berbagi pengetahuan. Hasil penelitian ini menunjukkan bahwa masa kerja guru tidak mempengaruhi perilaku berbagi pengetahuan. Hasil masa kerja yang tidak terkait dengan perilaku berbagi pengetahuan ini bertentangan dengan anggapan bahwa guru yang lebih berpengalaman akan bersemangat membagi pengetahuan kepada rekan guru yang lebih muda dan kurang berpengalaman; sebaliknya, guru yang kurang berpengalaman diharapkan bersemangat terlibat dalam mengumpulkan pengetahuan.

Hasil yang diperoleh dalam penelitian ini mungkin disebabkan oleh fakta bahwa terlepas dari masa kerja mereka, guru cenderung memiliki tingkat pendidikan yang sama. Hal ini dikuatkan dengan pendapat Mogotsi, Boon, \& Fletcher (2011) yang menyatakan bahwa guru mungkin merasa memiliki tingkat keahlian yang sama, dan dengan demikian memiliki sedikit motivasi untuk berbagi pengetahuan, baik itu memberikan ataupun mengumpulkan pengetahuan. Selain itu, banyak keahlian yang mungkin perlu mereka akses mungkin terkait dengan konten yang dapat diperoleh dari buku dan sumber informasi lainnya tanpa sepengetahuan rekan kerja.

Pada penelitian ini, variabel antesenden yang diteliti adalah trait conscientiousness, leader-member exchange dan masa kerja. Perilaku berbagi pengetahuan dipengaruhi oleh banyak faktor lain selain tiga variabel tersebut, oleh karena itu pada penelitian-penelitian selanjutnya bisa dilakukan dengan menambahkan variabel-variabel yang terkait dengan perilaku berbagi pengetahuan seperti trust, dukungan sosial dan efikasi diri.

Hasil penelitian ini dapat dimanfaatkan oleh sekolah sebagai saran dalam seleksi perekrutan guru. Seleksi berdasarkan tes kepribadian dengan skor tinggi pada trait conscientiousness dapat menjadi indikator kemungkinan guru di masa depan terlibat dalam perilaku berbagi pengetahuan dan melakukan tugas dengan lebih baik. Hal ini penting karena trait kepribadian ini dapat berdampak pada perilaku berbagi pengetahuan guru dan kemungkinan efektivitas organisasi.

Bagi Kepala Sekolah, sebagai peimpin di sekolah, diharapkan dapat mengembangkan hubungan yang dekat dan suportif dengan guru sebagai cara untuk meningkatkan perilaku berbagi pengetahuan antar guru. Bagi guru, penelitian ini diharapkan dapat membuat guru lebih memahami pentingnya aktivitas berbagi pengetahuan dengan sesama rekan guru untuk mencapai tujuan organisasi serta membantu dalam pengembangan dirinya. 


\section{SIMPULAN}

Berdasarkan hasil yang telah dikemukakan di atas, dapat ditarik kesimpulan bahwa trait conscientiousness guru dan leader-member exchange memiliki pengaruh secara positif signifikan terhadap perilaku berbagi pengetahuan guru, sedangkan masa kerja ditemukan tidak berpengaruh secara signifikan terhadap perilaku berbagi pengetahuan.

\section{DAFTAR PUSTAKA}

Agyemang, F.G. Dzandu, M.D. \& Boateng, H. (2016). Knowledge Sharing among Teachers: the Role of the Big Five Personality Traits. VINE Journal of Information and Knowledge Management Systems, 46(1): 64-84.

Asrar-ul-Haq, M. \& Anwar, S. (2016). A Systematic Review of Knowledge Management and Knowledge Sharing: Trends, Issues, and Challenges. Cogent Business $\mathcal{E}$ Management, 3(1): 1127744.

Badar, E.F. \& Seniati, A.N.L. (2017). Pengaruh Trust terhadap Berbagi Pengetahuan melalui Mediasi Komitmen Organisasi pada Dosen Perguruan Tinggi. Jurnal Indigenous, 2(1): 7-27.

Barrick, M.R. Mount, M.K. \& Judge, T.A. (2001). Personality and Performance at the Beginning of the New Millennium: What Do We Know and Where Do We Go Next?. International Journal of Selection and assessment, 9(1-2): 9-30.

Borges, R. (2013). Tacit Knowledge Sharing Between IT Workers: The Role of Organizational Culture, Personality, And Social Environment. Management Research Review, 36(1): 89-108.

Cabrera, E.F. \& Cabrera, A. (2006). Fostering Knowledge Sharing through People Management Practices, The International Journal of Human Resource, 37-41.

Carmeli, A. Atwater, L. \& Levi, A. (2011). How Leadership Enhances Employees' Knowledge Sharing: The Intervening Roles of Relational and Organizational Identification. The Journal of Technology Transfer. 36(3): 257-274.
Chen, C.C. (2011). Factors Affecting High School Teachers' knowledge Sharing Behaviors. Social Behavior and Personality, 39(7): 993.

Gupta, B. (2008). Role of Personality in Knowledge Sharing and Knowledge Acquisition Behaviour. Journal of the Indian Academy of Applied Psychology, 34(1): 143-149.

Istono, M. (2018). Hubungan Gaya Kognitif, Employee Voice Behavior, Leader-Member Exchange, Keader Self Efficacy, dan Interpretasi Isu pada Pejabat Madya Pemerintah Daerah, Disertasi. Depok: Universitas Indonesia.

Judge, T. A. Rodell, J. B. Klinger, R. L., Simon, L. S., \& Crawford, E. R. (2013). Hierarchical Representations of the Five-Factor Model Of Personality in Predicting Job Performance: Integrating Three Organizing Frameworks with Two Theoretical Perspectives. Journal of Applied Psychology, 98(6): 875 .

Kim, S.L. Han, S. Son, S.Y. \& Yun, S. (2017). Exchange Ideology in SupervisorSubordinate Dyads, LMX, and Knowledge Sharing: A Social Exchange Perspective. Asia Pacific Journal of Management, 34(1): 147-172.

Kim, S. L. \& Yun, S. (2015). The Effect of Coworker Knowledge Sharing on Performance And Its Boundary Conditions: An Interactional Perspective. Journal of Applied Psychology, 100(2): 575.

Kishore, J.K. Sandhu, M.S. \& Goh, S.K. (2015). Organizational Climate, Trust and Knowledge Sharing: Insights from Malaysia. Journal of Asia Business Studies, 9(1): 54-77.

Latham, G.P., \& Pinder, C.C. (2005). Work Motivation Theory and Research at the Dawn of the Twenty-First Century. Annual Review Psychology, 56(1): 485-516.

Liden, R.C. \& Maslyn, J. (1998). Multidimensionality of Leader-Member Exchange: An Empirical Assessment Through Scale Development. Journal of Management, 24: 43-72.

Lotfi, M. Muktar, S.N.B. Ologbo, A.C. \& Chiemeke, K.C. (2016). The Influence of the Big-Five Personality Traits Dimensions on Knowledge Sharing Behavior. Mediterranean Journal of Social Sciences, $7(1): 241$.

Mallasi, H. \& Ainin, S. (2015). Investigating Knowledge Sharing Behaviour in Academic Environment. Journal of Organizational Knowledge Management, 2015: 1-20. 
Matić, D. Cabrilo, S. Grubić-Nešić, L. \& Milić, B. (2017). Investigating the Impact of Organizational Climate, Motivational Drivers, and Empowering Leadership on Knowledge Sharing. Knowledge Management Research E Practice, 15(3): 431446.

Matzler, K. Renzl, B. Mooradian, T. von Krogh, G. \& Mueller, J. (2011). Personality Traits, Affective Commitment, Documentation of Knowledge, and Knowledge Sharing. The International Journal of Human Resource Management, 22(02): 296-310.

McCrae, R. R \& Costa Jr, P. T. (1992). Four Ways Five Factors are Basic. Personality and Individual Differences, 13: 653-665.

Mogotsi, I. C. Boon, J. H. \& Fletcher, L. (2011). Knowledge Sharing Behaviour And Demographic Variables amongst Secondary School Teachers in and Around Gaborone, Botswana. South African Journal of Information Management, 13(1): 1-6.

Morrow, P.C. \& McElroy, J.C. (1987). Work Commitment and Job Satisfaction Over Three Career Stage. Journal of Vocational Behavior, 30(3): $330-346$.

Okyere-Kwakye, E. \&Nor, K.M. (2011). Individual Factors and Knowledge Sharing. American Journal of Economics and Business Administration, 3(1), 66-72.

Raducanu, R.R. (2012). Assessment of Employees' Attitudes and Intentions to Share Knowledge Based on Their Individual Characteristics. Unpublished Master's Dissertation Copenhagen: Copenhagen Business School.

Rismark, M. \& Solvberg, A.M. (2011). Knowledge Sharing in Schools: A Key to Developing Professional Learning Communities. World Journal of Education, 1(2): 150-160.

Runhaar, P. \& Sanders, K. (2015). Promoting Teachers' Knowledge Sharing: The Fostering Roles of Occupational SelfEfficacy and Human Resources Management. Educational Management Administration $\mathcal{E}$ Leadership, 44(5): 794-813.

Robbins, S.P. \& Judge, T.A. (2015). Perilaku Organisasi. Jakarta: Salemba Empat.

Sarti, D. (2018). Organizational Tenure and Knowledge-Sharing Behaviours: The Moderating Role of Leader-Member Exchange. Journal of Workplace Learning, 30(4): 291-307.

Seba, I. Rowley, J. \& Delbridge, R. (2012). Knowledge Sharing in the Dubai Police
Force. Journal of Knowledge Management, 16: 114-128.

Seniati, L. (2002). Pengaruh Masa Kerja, Trait Kepribadian, Kepuasan Kerja, dan Iklim Psikologis Terhadap Komitmen Dosen pada Universitas Indonesia. Hubs-Asia, 10(1): 8897.

Sharifkhani, M. Pool, K.J. \& Asian, S. (2016). The Impact of Leader-Member Exchange on Knowledge Sharing and Performance: An Empirical Investigation in the Oil and Gas Industry. Journal of Science and Technology Policy Management, 7(3): 289-305.

van den Hooff, B. \& de Ridder, J.A. (2004). Knowledge Sharing In Context: The Influence of Organizational Commitment, Communication Climate and CMC Use on Knowledge Sharing. Journal of Knowledge Management, 8(6): 117-130.

Jolaee, A. Nor, K.M. Khani, N. \& Yusoff, R.M. (2014). Factors Affecting Knowledge Sharing Intention among Academic Staff. International Journal of Educational Management, 28(4): 413-431.

Wang, S. \& Noe, R.A. (2010). Knowledge Sharing: A Review and Directions for Future Research. Human Resource Management Review, 20(2): 115-131. 